\title{
Reproductive rate and calf body mass in a north-boreal reindeer herd: effects of NAO and snow conditions
}

\author{
Pekka Aikio ${ }^{1} \&$ Ilpo Kojola ${ }^{2}$ \\ 1) Reindeer herding cooperative of Lappi, Unarintie 17, Fl-99600 Sodankylä, Finland \\ (corresponding author's e-mail: siikapekka@gmail.com) \\ 2) Finnish Game and Fisheries Research Institute, Oulu Game and Fisheries Research, Tutkijantie \\ 2 E, Fl-90570 Oulu, Finland
}

Received 8 Apr. 2013, final version received 24 Apr. 2014, accepted 24 Dec. 2013

Aikio, P. \& Kojola, I. 2014: Reproductive rate and calf body mass in a north-boreal reindeer herd: effects of NAO and snow conditions. - Ann. Zool. Fennici 51: 507-514.

Population demographics of northern ungulates are influenced by density and weather conditions. For caribou and reindeer (Rangifer tarandus) that dig in the snow for winter food, snow accumulation and duration of the snow layer are suggested to be influential. Indices based on large-scale alterations of atmospheric pressure such as the North Atlantic Oscillation (NAO) are connected to climate change and may predict ecological processes better than does local weather. Some empirical evidence of the effects of climate variation is available for Arctic and alpine populations but practically none for sedentary, boreal reindeer. We examined the effects of population density, winter and spring NAO, snow accumulation, and the timing of snowmelt on reproductive success (here the calf/female ratio) and on mean summer body mass of calves in a north-boreal, free-ranging herd of semi-domesticated reindeer in northeastern Finland. In this herd, day of snowmelt explained variation in the calf/female ratio and in the midsummer body mass of calves, more so than NAO, winter snow depth and population density.

\section{Introduction}

Climatic variation causes variation in reproductive success in herbivore populations (Aanes et al. 2002, Chan et al. 2005, Post 2005, Vucetich et al. 2005, Veeroja et al. 2010). In northern ungulates, the depth and duration of the snow layer may be key factors influencing energy expenditure and reproductive success (Fancy \& White 1985, Ottersen et al. 2001, Stenseth et al. 2002, Weladji \& Holand 2006, Veeroja et al. 2010).

Indices based on large-scale alterations of atmospheric pressure, such as the North Atlantic
Oscillation (NAO) and the Arctic Oscillation (AO), are connected to climate change (Hurrell 1995, Forchammer \& Post 2000, Aanes et al. 2002, Weladji \& Holand 2006) with high precipitation and the resultant heavy accumulation of snow associated with high values of winter NAO (Weladji \& Holand 2003, Helle \& Kojola 2008). Spring NAO can also be influential. In coastal Norway, for example, high values of spring NAO are associated with higher temperatures and high precipitation and are, hence, favourable for reindeer (Rangifer tarandus; Pettorelli et al. 2005). Changes in the frequency and amplitude 
of these modes of climate variability affect ecological processes (Stenseth \& Hurrell 2005) and may explain these processes even better than local weather (Hallet et al. 2004, Stenseth \& Mysterud 2005).

In northern ungulates, such as reindeer, the thickness and hardness of snow affect energetic costs associated with foraging because they dig for winter forage beneath the snow (Fancy \& White 1985). In theory, one of the main factors influencing demographics in reindeer and caribou may be the timing of snowmelt because it can affect the energy balance of females during late pregnancy and after parturition (Caughley \& Gunn 1993, Post \& Klein 1999).

In this study, we examined density-dependent and density-independent annual variation in the calf/female ratio and in body mass of reindeer calves. Pregnancy rates are high and relatively constant in reindeer and caribou while the survival of newborns varies and forms one of the key factors in population dynamics (Reimers 1986, Rettie \& Messier 1998, Wittmer et al. 2005). Body mass is important for reproductive success in mammals (Calder 1996, Reimers 1997). We used 19-year-long data to evaluate the effects of winter population density, NAO, snow depth and the timing of snowmelt on reproductive success (here the calf/female ratio) and the midsummer body mass of calves in a herd of semi-domesticated, free-ranging reindeer in north-boreal woodlands.

\section{Material and methods}

\section{Study area}

Data were collected from a herd of semi-domesticated, free-ranging reindeer within a $4002 \mathrm{~km}^{2}$ area in eastern Finnish Lapland, around the village of Vuotso $\left(68^{\circ} 06^{\prime} \mathrm{N}, 27^{\circ} 08^{\prime} \mathrm{E}\right)$. The area belongs to the northern-boreal vegetation zone (Ahti et al. 1968). The two main landscape types are alpine highlands (ca. $40 \%$ of the land area) and boggy woodland $(60 \%)$. Scotch pine (Pinus sylvestris) and Norway spruce (Picea abies) are the dominant tree species. Data were collected as part of a study project focusing on the ecology of reindeer herding at the Research
Institute of northern Finland. During our study (1977-2000), the mean duration of the snowcovered season was 210 days (range 178-227 days). The main calving season is the two last weeks of May.

\section{Parameters}

We extracted winter density numbers and the calf/female ratio in mid-summer from official reindeer statistics kept by the Association of Reindeer Herders. These data are based on counts in summer (number of calves) and autumn round-ups (number of females). Countbased estimates can be misleading, especially in closed habitats (Bonenfant et al. 2005). This is likely negligible in our dataset because counts were performed in corrals by reindeer herders. Calves were ear-marked in summer round-ups. Round-ups were performed between 20 June and 15 July. The number of calves counted varied between days, but such variation could only marginally influence the calf/female ratio because the critical first few weeks of life occurred before round-ups and mortality during the round-up season is low $(<2 \%)$ in this herd (Norberg et al. 2006). Because reindeer is monoparous, the number of calves is the same as the number of females with calves. The number of females with calves and without calves was used when analysing the calf/female ratio.

A randomly selected sample of 6905 calves were sexed and weighed during mid-summer round-ups that took place between 20 June and 15 July. According to linear regression, weighing day correlated significantly with body mass $\left(r=0.321, F_{2,6903}=801.3, p<0.001\right)$, showing a $206 \mathrm{~g}$ mean daily weight gain. This daily gain in weight is somewhat lower than in experimental, fenced reindeer (270 g; Timisjärvi et al. 1982). Our data comprise 19 years from 1977 to 2000, and were primarily collected as part of a project focusing on the ecology reindeer herding. Data on calf weights were not available in 1980, 1981, 1991 and 1999.

We downloaded monthly values of the North Atlantic Oscillation (NAO) from www.cpc.noaa. gov, and used means for the period December-March as an index of winter NAO (Hurrell 
1996), and May NAO as an index of spring NAO. In continental climates, high winter NAO is associated with deep snow cover that increases the energetic costs of food acquisition by reindeer (Helle \& Kojola 2008). For local weather and snow conditions, we used daily measurements from the local meteorological station in Vuotso and calculated snow depth index that is the cumulative sum of daily snow depths for the entire snow-cover season and day of snowmelt (the first day in spring when snow depth was assigned as zero, days passed from the 1st of January). Because densities in the studied reindeer population were higher $\left(2.5-3.2 \mathrm{~km}^{-2}\right)$ than in boreal wild reindeer populations $\left(0.4-1.0 \mathrm{~km}^{-2}\right.$; COSEWIC 2002, Wittmer et al. 2005; I. Kojola unpubl. data) we expected the calf/female ratio and the mean body mass to behave in a densitydependent fashion.

\section{Model selection}

We predicted that population density of the previous winter, winter NAO, spring NAO, snowdepth index and day of snowmelt to affect calf/ female ratio and mean body mass of calves. We first calculated Pearson correlations $\left(r_{\mathrm{p}}\right)$ between these independent variables (Table 1). If pair-wise $r_{\mathrm{P}}$ between independent variables was greater than 0.5 , we did not enter these variables into the same model. Models (Tables 2 and 3) were ranked by using Akaike's information criterion corrected for small samples ( $\mathrm{AIC}_{\mathrm{c}}$; Anderson et al. 2001, Burnham \& Anderson 2002). We compared each of these models to the best model by calculating differences $(\triangle \mathrm{AIC})$ between the $\mathrm{AIC}_{\mathrm{c}}$ values (see Burnham and Anderson 2002). Model weights $\left(\mathrm{AIC}_{\mathrm{w}}\right)$, which indicate the probability of the best model, and adjusted $r^{2}$ values were also calculated.

Table 1. Pearson's correlation coefficients, $r_{\mathrm{p}}$, ( $p$ values in parantheses) between independent variables.

\begin{tabular}{lrrrr}
\hline Variable & Winter NAO & Spring NAO & Day of snowmelt & Snow depth index (cm) \\
\hline Density & $0.413(0.070)$ & $0.070(0.769)$ & $-0.056(0.814)$ & $0.347(0.134)$ \\
Snow depth index $(\mathrm{cm})$ & $-0.122(0.607)$ & $0.060(0.803)$ & $0.536(0.015)$ & \\
Day of snowmelt & $-0.552(0.012)$ & $-0.052(0.829)$ & \\
Spring NAO & $0.139(0.559)$ & & \\
\hline
\end{tabular}

Table 2. The most parsimonious models for the calf/female ratio in a north-boreal reindeer herd, Finland. The models are ranked by $\mathrm{AIC}_{\mathrm{c}}$ values.

\begin{tabular}{|c|c|c|c|c|c|c|c|c|}
\hline $\begin{array}{l}\text { Model } \\
\text { rank }\end{array}$ & $\begin{array}{c}\text { Day of } \\
\text { snowmelt }\end{array}$ & $\begin{array}{l}\text { Snow } \\
\text { depth } \\
\text { index }\end{array}$ & $\begin{array}{l}\text { Winter } \\
\text { NAO }\end{array}$ & $\begin{array}{c}\text { Spring } \\
\mathrm{NAO}\end{array}$ & $\begin{array}{c}\text { Population } \\
\text { density }\end{array}$ & $\Delta \mathrm{AIC}_{\mathrm{c}}^{\mathrm{a}}$ & $\mathrm{AIC}_{\mathrm{w}}{ }^{\mathrm{b}}$ & Adjusted $r^{2}$ \\
\hline 1 & $x$ & & & $x$ & & 0 & 0.353 & 0.55 \\
\hline 2 & $x$ & & & $x$ & $x$ & 0.20 & 0.319 & 0.56 \\
\hline 3 & $x$ & & & & & 1.94 & 0.134 & 0.48 \\
\hline 4 & $x$ & & & & $x$ & 2.79 & 0.09 & 0.48 \\
\hline 5 & & $x$ & $x$ & $x$ & & 3.45 & 0.06 & 0.50 \\
\hline 6 & & $x$ & $x$ & & & 5.51 & 0.02 & 0.43 \\
\hline 7 & & & $x$ & $x$ & & 6.62 & 0.01 & 0.38 \\
\hline 8 & & & $x$ & & & 8.39 & 0.01 & 0.30 \\
\hline 9 & & $x$ & & & & 11.69 & 0 & 0.16 \\
\hline 10 & & $x$ & & $x$ & & 12.29 & 0 & 0.16 \\
\hline 11 & & & & $x$ & & 14.20 & 0 & 0.01 \\
\hline 12 & & & & & $x$ & 14.82 & 0 & 0 \\
\hline 13 & & & & $x$ & $x$ & 15.71 & 0 & 0 \\
\hline
\end{tabular}

${ }^{\text {a }}$ difference between the current model and the minimum AIC value corrected for small samples.

${ }^{\mathrm{b}}$ model weight. 


\section{Results}

\section{Trends in variables}

Winter reindeer density ranged between 1.0 and 2.8 indiv. $\mathrm{km}^{-2}$, increasing from the late $1970 \mathrm{~s}$ to the end of the 1980s and decreasing thereafter (Fig. 1). The calf/female ratio was similar to the trend in winter reindeer density, while mean body mass decreased and day of snowmelt occurred later during the study period (Fig. 1).

\section{Reproduction}

Low calf/female ratio was associated with years of late snowmelt (Table 2 and Fig. 2). The bestfit model (model 1; see Table 2) (probability of 0.94) explaining calf/female ratio included day of snowmelt and spring NAO. The second-best model (model 2) included day of snowmelt, spring $\mathrm{NAO}$ and population density $\left(\triangle \mathrm{AIC}_{\mathrm{c}}=\right.$ 0.20 ; see Table 2$)$. The best-fit model $\left(\Delta \mathrm{AIC}_{\mathrm{c}}=\right.$ 3.45 ; see Table 2) without day of snowmelt was model 5 including snow-depth index as well as winter and spring NAO. The fit of model 7 with spring and winter NAO as the only independent variables was very poor $\left(\Delta \mathrm{AIC}_{\mathrm{c}}=6.26\right.$; see Table 2).

\section{Calf body mass}

Mean body mass of calves also decreased with the delay of snowmelt (Fig. 2). The best-fit model (model 1; see Table 3) (probability of 0.94 ) included day of snowmelt and population density. Model 2, in which population density was the third variable together with day of snowmelt and spring $\mathrm{NAO}$, and model 3 , in which the day of snowmelt was the independent variable, provided only slightly weaker fits with mean body mass. Model 4, ranking highest of all models without day of snowmelt, had notably lower fit than the best-fit model $\left(\Delta \mathrm{AIC}_{\mathrm{c}}=3.68\right)$. Mean body mass was significantly correlated with the calf/female ratio $\left(r_{\mathrm{P}}=0.457, p=0.043\right)$.

\section{Discussion}

Our results demonstrated that the timing of snowmelt and population density were important for the reproductive success (here the calf/ female ratio) and calf body mass in a northboreal reindeer herd. This result supports the hypothesis of favourable effects of early spring on reindeer population dynamics (Caughley \& Gunn 1993, Post \& Klein 1999, Pettorelli et al. 2005). Furthermore, even dwarf shrubs and dead grass that reindeer eat from the first snow-free

Table 3. The most parsimonious models for mean calf mass in midsummer in a north-boreal reindeer herd, Finland. The models are ranked by $\mathrm{AIC}_{\mathrm{c}}$ values.

\begin{tabular}{|c|c|c|c|c|c|c|c|c|}
\hline $\begin{array}{l}\text { Model } \\
\text { rank }\end{array}$ & $\begin{array}{c}\text { Day of } \\
\text { snowmelt }\end{array}$ & $\begin{array}{l}\text { Snow } \\
\text { depth } \\
\text { index }\end{array}$ & $\begin{array}{c}\text { Winter } \\
\text { NAO }\end{array}$ & $\begin{array}{l}\text { Spring } \\
\text { NAO }\end{array}$ & $\begin{array}{c}\text { Population } \\
\text { density }\end{array}$ & $\Delta \mathrm{AIC}_{\mathrm{c}}{ }^{\mathrm{a}}$ & $\mathrm{AlC}_{\mathrm{w}}{ }^{\mathrm{b}}$ & Adjusted $r^{2}$ \\
\hline 1 & $x$ & & & & $x$ & 0.00 & 0.48 & 0.43 \\
\hline 2 & $x$ & & & $x$ & $x$ & 1.63 & 0.21 & 0.40 \\
\hline 3 & $x$ & & & & & 1.86 & 0.19 & 0.34 \\
\hline 4 & & $x$ & & $x$ & & 3.68 & 0.08 & 0.31 \\
\hline 5 & & $x$ & & & & 7.09 & 0.01 & 0.15 \\
\hline 6 & & $x$ & & $x$ & & 8.65 & 0.01 & 0.12 \\
\hline 7 & & $x$ & $x$ & & & 8.65 & 0.01 & 0.12 \\
\hline 8 & & & & & $x$ & 9.56 & 0 & 0.04 \\
\hline 9 & & $x$ & $x$ & $x$ & & 10.32 & 0 & 0.08 \\
\hline 10 & & & $x$ & & & 10.69 & 0 & 0.02 \\
\hline 11 & & & & $x$ & & 11.16 & 0 & 0.04 \\
\hline 12 & & & & $x$ & $x$ & 11.21 & & 0 \\
\hline 13 & & & $x$ & $x$ & & 11.55 & & 0.07 \\
\hline
\end{tabular}

${ }^{a}$ difference between the current model and the minimum AIC value corrected for small samples.

${ }^{\mathrm{b}}$ model weight. 

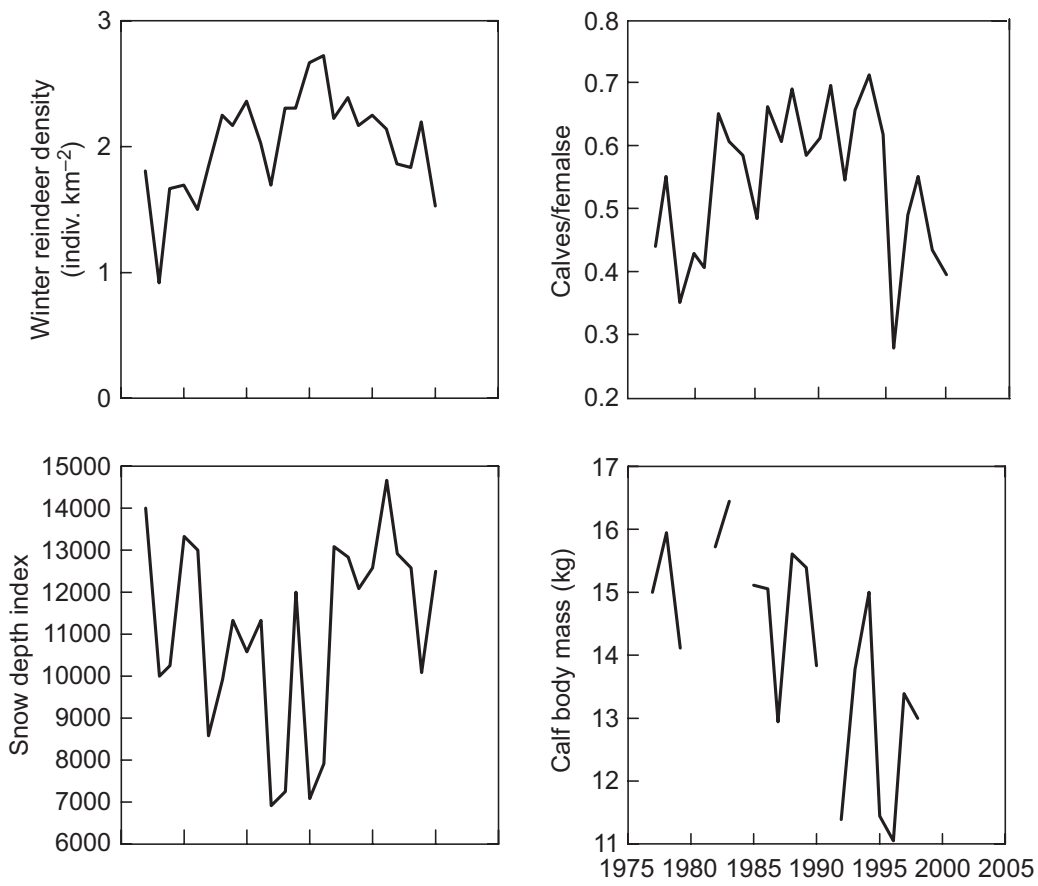

Fig. 1. Yearly variation in winter density of reindeer, calf/female ratio, snow depth index, mean midsummer body mass of calves and day of snowmelt in Vuotso, northeastern Finland.
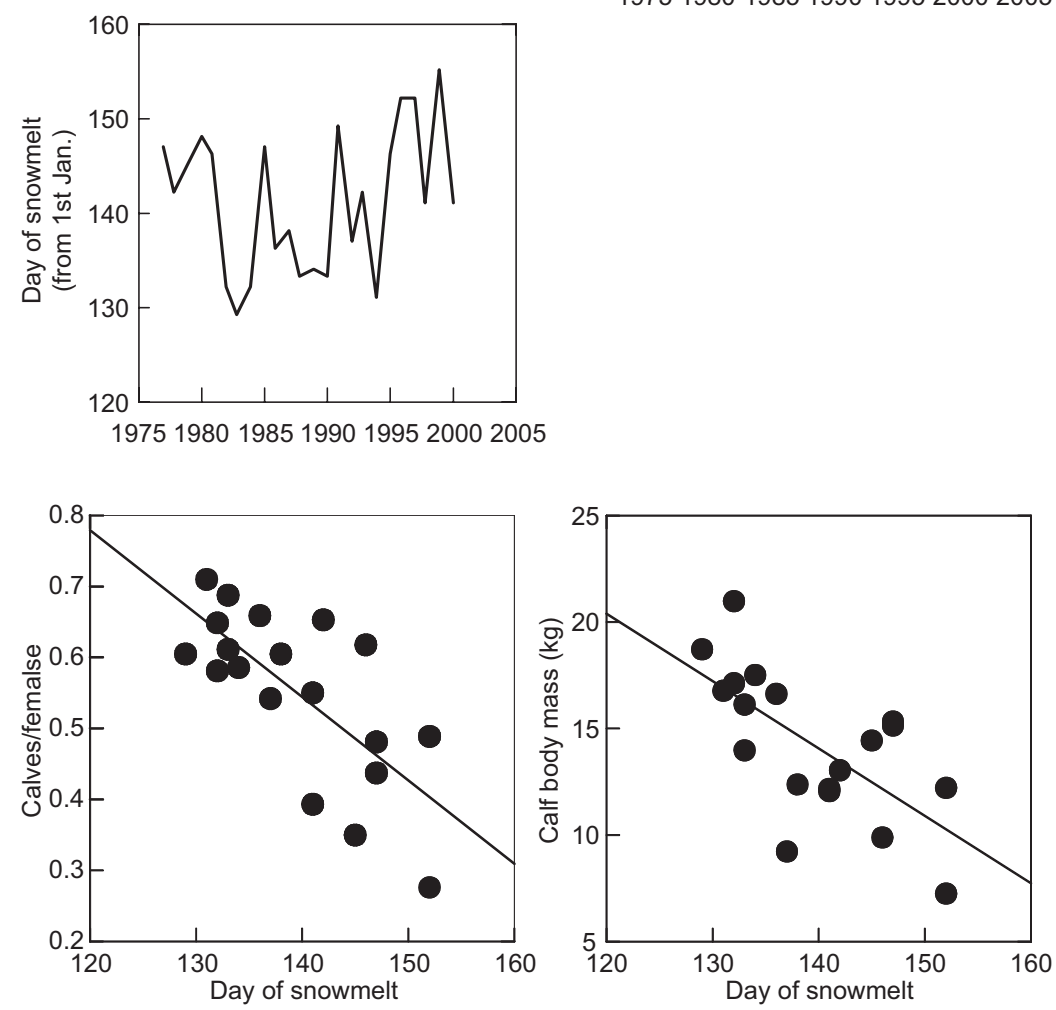

Fig. 2. Relationships between day of snowmelt and calf/female ratio, and mean body mass of calves in Vuotso, northeastern Finland.

affects growth rate and survival of calves (Créte

patches might be important (Ryd 2001, Fauchald et al. 2004). Availability of green forage improves milk production of females, which
\& Huot 1993, Post \& Klein 1999, Tveraa et al. 2003). 
Associations between the NAO index and local snow conditions were not conclusive. The negative correlation between winter NAO and early snowmelt contradicted our expectations because high NAO values usually correlate with precipitation (Stenseth et al. 2002, Helle \& Kojola 2008), and high precipitation in winter results in increased snow depth. In our study area, snow accumulation in winter was not linked to the NAO values. Early snowmelt after winters with high NAO values demonstrates how problematic it may be to predict ecological processes in individual populations using values of climatic oscillation indices. Mysterud et al. (2001) demonstrated that the impact of NAO on local snow depth in Norway may be both negative and positive depending on the position of a meteorological station. In northern Finland, daily temperature and precipitation in winter correlate with NAO at all meteorological stations, but snow depths were not related to NAO (I. Kojola unpubl. data).

Another commonly used index in this context, the Arctic Oscillation (AO), predicts local weather better than NAO in high Arctic ecosystems (Aanes et al. 2002). These two indices are highly correlated and in our study area AO did not predict snow accumulation and the timing of snowmelt better than NAO (I. Kojola unpubl. data).

The positive correlation between calf/female ratio and mean body mass of calves provides evidence of the importance of the timing of snowmelt because the smallest calves are most prone to die as newborns (Eloranta \& Nieminen 1986). The association between juvenile body mass and survival might reduce the effects of cohorts born in adverse years on population dynamics. Furthermore, selective culling, decreases the proportion of animals originating from weak cohorts.

We did not find clear evidence of density dependence. In theory, density-dependent variation in ungulate population demographics is less evident at higher altitudes where animals are exposed to harsh and stochastically varying climatic conditions (Caughley \& Gunn 1993, Post 2005). Density-dependence is less likely in Finnish than in e.g. Norwegian herding system because most of the Finnish herds receive supplementary food in winter (Helle \& Kojola 1993,
Kojola \& Helle 1993). Furthermore, densitydependence in juvenile survival may be difficult to detect when survival is also affected by density-independent factors (Portier et al. 1998).

One factor that is crucial in snow conditions is the formation of ice on the ground, which occurs occasionally in alpine and Arctic ranges and seriously hampers access to ground forage (Chan et al. 2005, Helle \& Kojola 2008). Our study area is partly located within the alpine highlands but reindeer could move into woodlands at low altitudes where icing does not occur.

To summarize, our results demonstrate a strong effect of the onset of spring on the calf/ female ratio and on the growth of calves. Scenarios of the effects of global warming on local weather are variable (see Weladji \& Holand 2006 for a review). Therefore, it is difficult to forecast the effects of warming on population demographics of Arctic ungulates. Early snowmelt is favourable but high summer temperatures are not, as they cause higher activity (hence higher energy loss) of reindeer trying to avoid blood-sucking and parasitic insects (Helle \& Tarvainen 1984, Helle \& Kojola 1994). Climate change may decrease reproductive success of migratory caribou through trophic mismatch because timing of their spring migration to calving grounds is cued primarily by changes in day length, and the timing between day length and plant phenology may change (Post \& Forchhammer 2008). For subarctic reindeer that do not perform extensive seasonal migrations, the early onset of spring is favourable (Tveraa et al. 2013). Furthermore, a recent study has shown that reindeer's capacity as a capital breeder minimizes the effects of stochastic climate conditions on its population dynamics (Taillon et al. 2013).

\section{Acknowledgements}

We would like to acknowledge economic support from the SITRA fund and local reindeer herders who assisted in data collection. Antti Paasivaara helped with the statistical analyses.

\section{References}

Aanes, R., Sæther, B. E., Smith, F. M., Cooper, E. J., 
Wookey, P. A. \& Øritsland, N. A. 2002: The Arctic Oscillation predicts effects of climate change in two trophic levels in a high-arctic ecosystem. - Ecology Letters 5: 445-453.

Ahti, T., Hämet-Ahti, L. \& Jalas, J. 1968: Vegetation zones and their sections in northwestern Europe. - Annales Botanici Fennici 5: 169-211.

Anderson, R. A., Link, W. A., Johnson, D. H. \& Burnham, K. P. 2001: Suggestions for presenting the results of data analyses. - Journal of Wildlife Management 65: 373-378.

Bonenfant, C., Gaillard, J.-M., Klein, F. \& Hamann, J.-L. 2005: Can we use young:female ratio to infer ungulate population dynamics? An empirical test using red deer Cervus elaphus as a model. - Journal of Applied Ecology 42: 361-370.

Burnham, K. \& Anderson, D. 2002: Model selection and inference: a practical information-theoretic approach. - Springer, New York.

Calder, W. A. I. 1996: Size, function and life history. Dover Publications, Mineola, New York.

Caughley, G. \& Gunn, A. 1993: Dynamics of large herbivores in deserts: kangaroos and caribou. - Oikos 67: $47-55$.

Chan, K.-S., Mysterud,A., Øritsland, N. A., Severinsen, O. \& Stenseth, N. C. 2005: Continuous and discrete extreme climatic events affecting the high-arctic reindeer populations. - Oecologia 145: 556-563.

COSEWIC 2002: Assessment and update status report on the woodland caribou Rangifer tarandus caribou. COSEWIC Committee on the status of endangered wildlife in Canada.

Créte, M. \& Huot, J. 1993: Regulation of a large herd of a migratory caribou: summer nutrition affects calf growth and body reserves of dams. - Canadian Journal of Zoology 71: 2291-2296.

Eloranta, E. \& Nieminen, M. 1986: Calving of the experimental reindeer herd in Kaamanen during 1970-85. Rangifer, Special Issue 1: 115-121.

Fancy, S. G. \& White, R. G. 1985: Energy expenditure by caribou while cratering in snow. - Journal of Wildlife Management 49: 987-993.

Fauchald, P., Tveraa, T., Henaug, C. \& Yoccoz, N. 2004: Adaptive regulation of body reserves in reindeer; Rangifer tarandus; a feeding experiment. - Oikos 107: 583-591.

Forchammer, M. C. \& Post, E. 2000: Climatic signatures in ecology. - Trends in Ecology and Evolution 5: 286.

Hallett, T. B., Coulson, T., Pilkington, J. G., Clutton-Brock T. H., Pemberton, J. M. \& Grenfell, B. 2004: Why largescale climate predicts ecological processes better than local weather? - Nature 430: 71-75.

Helle, T. \& Kojola, I. 1993: Reproduction and mortality of Finnish semi-domesticated reindeer in relation to density and management strategies. - Arctic 46: 72-77.

Helle, T. \& Kojola, I. 1994: Body mass variation in semidomesticated reindeer. - Canadian Journal of Zoology 72: 681-688.

Helle, T. \& Kojola, I. 2008: Demographics in an alpine reindeer herd: effects of density and winter weather. -
Ecography 31: 221-230.

Helle, T. \& Tarvainen, L. 1984: Effects of insect harassment on weight gain and survival of reindeer calves. - Rangifer 4: 24-27.

Hurrell, J. W. 1995: Decadal trends in North Atlantic Oscillation: regional temperatures and precipitations. - Science 269: 676-679.

Hurrell, J. W. 1996: Influence of variations in extratropical wintertime teleconnections on northern hemisphere temperatures. - Geophysical Research Letters 23: 665-668.

Kojola, I. \& Helle, T. 1993: Calf harvest and reproductive rate of reindeer in Finland. - Journal of Wildlife Management 57: 451-453.

Mysterud, A., Stenseth, N. C., Yoccoz, N. G., Langvatn, R. \& Steinheim, G. 2001: Nonlinear effects of large-scale variability on wild and domestic herbivores. - Nature 410: 1096-1099.

Norberg, H., Kojola, I., Aikio, P. \& Nylund, M. 2006: Predation by golden eagle on semidomesticated reindeer in eastern Finnish Lapland. - Wildlife Biology 12: 393-402.

Ottersen, G., Planque, B., Belgrano, A., Post, E., Reid, P. C. \& Stenseth, N. C. 2001: Ecological effects of the North Atlantic Oscillation. - Oecologia 128: 1-14.

Pettorelli, N., Weladji, R. B., Holand, Ø., Mysterud, A., Breie, H. \& Stenseth, N. C. 2005: The relative role of winter and spring conditions: linking climate and landscape-scale plant phenology to alpine reindeer body mass. - Biology Letters 1: 24-26.

Portier, C., Festa-Bianchet, M., Gaillard, J.-M., Jorgenson, J. T. \& Yoccoz, N. G. 1998: Effects of density and weather on survival of bighorn sheep lambs (Ovis canadensis). - Journal of Zoology 245: 271-278.

Post, E. 2005: Large-scale spatial gradients in herbivore population dynamics. - Ecology 86: 2320-2328.

Post, E. \& Forchhammer, M. C. 2008: Climate change reduces reproductive success of an Arctic herbivore through trophic mismatch. - Philosophical Transactions of the Royal Society B 363: 2367-2373.

Post, E. \& Klein, D. 1999: Caribou calf production and seasonal range quality during a population decline. - Journal of Wildlife Management 63: 335-345.

Reimers, E. 1986: Management of wild reindeer in Norway. - Rangifer, Special Issue 1: 241-246.

Reimers, E. 1997: Rangifer population ecology: a Scandinavian perspective. - Rangifer 17: 105-118.

Rettie, W. J. \& Messier, F. 1998: Dynamics of woodland caribou populations at the southern limit of their range in Saskatchewan. - Canadian Journal of Zoology 76: 251-259.

Ryd. Y. 2001: Snö. - Ordfront, Stockholm.

Stenseth, N. C. \& Hurrell, J. W. 2005: Global climate change: building links between the climate and ecosystem impact research communities. - Climate Research 29: 181-182.

Stenseth, N. C. \& Mysterud, A. 2005: Weather packages: finding the right scale and composition in ecology. Journal of Animal Ecology 74: 1195-1198.

Stenseth, N. C., Mysterud, A., Ottersen, G., Hurrell, J. W., Chan, K.-S. \& Lima, M. 2002: Ecological effects of cli- 
mate fluctuations. - Science 297: 1292-1296.

Taillon, J. P., Barboza, P. S. \& Cote, S. D. 2013: Nitrogen allocation to offspring and milk production in a capital breeder. - Ecology 94: 1815-1827.

Timisjärvi, J., Nieminen, M., Roine, K., Koskinen, M. \& Laaksonenn, H. 1982: Growth in reindeer. - Acta Veterinaria Scandinavica 23: 603-618.

Tveraa, T., Fauchald, P., Henaug, C. \& Yoccoz, N. G. 2003: An examination of a compensatory relationship between food limitation and predation in semi-domesticated reindeer. - Oecologia 137: 370-376.

Tveraa, T., Stien, A., Bårdsen, B.-J. \& Fauchald, P. 2013: Population densities, vegetation green-up, and plant productivity: impacts on reproductive success and juvenile body mass in reindeer. - Plos ONE 8(2), 1-8, doi: 10.1371/journal.pone .0056450 .

Veeroja, R., Kirk, A., Tilgar, V., Säde, S., Kreitsberg, M. \&
Tönisson, J. 2010: Conception date affects litter type and foetal sex ratio in female moose in Estonia. - Journal of Animal Ecology 79: 169-175.

Vucetich, J. A., Smith D. W. \& Stahler, D. R. 2005: Influence of harvest, climate and wolf predation on Yellowstone elk, 1961-2004. - Oikos 111: 259-270.

Weladji, R. B. \& Holand, Ø. 2003: Global climate change and reindeer: effects of winter weather on the autumn weight and growth of calves. - Oecologia 136: 317323.

Weladji, R. B. \& Holand, Ø. 2006: Influences of large-scale climatic variability on reindeer population dynamics: implications for reindeer husbandry in Norway. - Climate Research 32: 119-127.

Wittmer, H. U., Sinclair, A. R. E. \& McLellan, B. 2005: The role of predation in the decline and extirpation of woodland caribou. - Oecologia 144: 257-267. 